\title{
International Criminal Justice and the Empowerment or Disempowerment of Victims
}

\author{
Chris Tenove*
}

In David Scheffer's memoir of his time as the United States' Ambassador-at-Large for War Crimes Issues, he reflects on his efforts to push colleagues in government to take stronger action on international criminal justice:

Often, while listening to senior officials sitting comfortably in the White House Situation Room explain why other national priorities trumped atrocities and the pursuit of war criminals, I wanted ... [the] mutilated bodies and missing souls of girls, boys, women and men of Bosnia, Rwanda, eastern Congo, and Sierra Leone to file silently through that wood-paneled room and remind policy-makers of the fate of ordinary human beings. ${ }^{1}$

Scheffer, like many advocates of international criminal justice, promotes its rules and institutions by referring to the suffering of victims and their need for redress. Indeed, commentators have observed that the legitimacy of international criminal justice is increasingly evaluated according to whether it provides 'justice for victims."

The passage by Scheffer is telling in another way. The role for victims in his imaginary scene is to wait silently for decision-makers to speak on their behalf. Critical scholars often make just this accusation - that victims are effectively voiceless and powerless in international criminal justice processes. Some go further and argue that international criminal tribunals de-politicize, render passive, or otherwise disempower victims as agents of justice. ${ }^{3}$ Concerns about the powerlessness or disempowerment of victims in international criminal justice processes are central to debates about whether international criminal justice does in fact advance 'justice for victims.'

* Postdoctoral Research Fellow, Department of Political Science, University of British Columbia, Vancouver, Canada. Correspondence: mail@tenove.com.

${ }^{1}$ David Scheffer, All the Missing Souls: Personal History of the War Crimes Tribunals, Princeton University Press, Princeton, 2013, p. 2.

${ }^{2}$ Laurel E. Fletcher, "Refracted Justice: The Imagined Victim and the International Criminal Court," in Christian De Vos, et al. (eds.), Contested Justice: The Politics and Practice of International Criminal Court Interventions, Cambridge University Press, Cambridge, 2016; Kjersti Lohne, "NGOs for International Justice: Criminal or Victims' Justice?," in Andreas Follesdal and Geir Ulfstein (eds.), The Judicialization of International Law: A Mixed Blessing?, Oxford University Press, Oxford, 2018.

${ }^{3}$ See, among others: Adam Branch, "Uganda's Civil War and the Politics of ICC Intervention," in Ethics \& International Affairs, 2007, vol. 21, no. 2; Kamari Maxine Clarke, Fictions of Justice: The International Criminal Court and the Challenges of Legal Pluralism in Sub-Saharan Africa, Cambridge University Press, Cambridge, 2009; Julie Mertus, "Shouting from the Bottom of the Well the Impact of International Trials for Wartime Rape on Women's Agency," in International Feminist Journal of Politics, 2004, vol. 6, no. 1. 
This chapter examines ways in which international criminal justice processes may empower or disempower victims in their pursuit of justice. ${ }^{4}$ Based on focus group discussions and interviews with survivors of conflict and international crimes in Kenya and Uganda, I argue that neither the laudatory nor critical positions in this debate capture the very complex and variegated effects of international criminal justice processes on victims.

I develop this argument in four sections. Section One explains how issues of victim empowerment and disempowerment have been addressed in literature on the field of international criminal justice (ICJ). ${ }^{5}$ Section Two describes my approach to research conducted with survivors of violence in Kenya and Uganda. Section Three summarizes this research and identifies key aspirations, concerns, and judgements regarding empowerment and disempowerment by the International Criminal Court (ICC). Section Four analyzes these findings and argues that international criminal justice processes do not simply empower or disempower victims. Instead, tribunals are selective about who receives victim status, they channel people's agency in particular ways, and their impact is highly context-dependent. As a result, victim status is not simply empowering or disempowering - it enhances the agency of some people in some contexts to pursue some justice aims, but it can also pose serious risks and constraints. The concluding section sketches some implications of this framework for understanding the power of international criminal justice, and for evaluating the capacity of international criminal tribunals to advance justice for victims.

Before developing this argument, I acknowledge that victim empowerment is not a universallyaccepted aim for international criminal justice. For many people, and particularly those with a background in Anglo-American legal systems, criminal justice processes should focus on the innocence, guilt, and just desserts of perpetrators. Doing so enables the state (or in this case the international community) to "displace" victims and their supporters from seeking justice or revenge themselves. ${ }^{6}$ Furthermore, commentators and practitioners have raised valid concerns that focusing on victims' interests or views may undermine the truth-seeking quality of trials, may lead to violations of the rights of the accused, and may fritter limited resources. ${ }^{7}$

\footnotetext{
${ }^{4}$ This chapter uses the term 'victims' to refer to people who are recognized as victims by international criminal tribunals. In the empirical research that follows, I refer to those who experienced rights violations as survivors, since not all were seeking victim status.

${ }^{5}$ On international criminal justice as a 'field,' see Peter Dixon and Chris Tenove, "International Criminal Justice as a Transnational Field: Rules, Authority and Victims," in International Journal of Transitional Justice, 2013, vol. 7, no. 3.

${ }^{6}$ On the "displacement function" of criminal justice, see John Gardner, "Crime: In Proportion and in Perspective," Offences and Defences: Selected Essays in the Philosophy of Criminal Law, Oxford University Press, Oxford, 2007.

${ }^{7}$ See, among others, Sofia Stolk, "The Victim, the International Criminal Court and the Search for Truth: On the Interdependence and Incompatibility of Truths About Mass Atrocity," in Journal of International Criminal Justice, 2015, vol. 13, no. 5; Christine Van den Wyngaert, "Victims before International Criminal Courts: Some Views and Concerns of an ICC Trial Judge," in Case Western Reserve University Journal of International Law, 2012, vol. 44; Sergey Vasiliev, "Victim Participation Revisited: What the ICC Is Learning About Itself," in Carsten Stahn (ed.), The Law and Practice of the International Criminal Court, Oxford University Press, Oxford, 2015; Natalie von Wistinghausen, "Victims as Witnesses: Views from the Defence," Victims of International Crimes: An Interdisciplinary Discourse, Springer, 2013.
} 
It is beyond the scope of this chapter to provide a full normative justification for highlighting the empowerment or disempowerment of victims in ICJ. However, I would make several points. First, while victim empowerment may be controversial, concern about disempowerment is not: few people would support actions by international criminal tribunals that increase survivors' vulnerability to harm or that undermine their capacities to address injustice. Second, as I have argued elsewhere, greater attention to survivors' perspectives can enable those people deeply affected by injustice, and who often have significant insight into its causes and consequences, to productively contribute to deliberations regarding the findings, operations, and ambitions of ICJ. ${ }^{8}$ Third, survivors and their allies can benefit from clearer understandings of the risks and opportunities that people may face in ICJ, leading to more realistic expectations for tribunals. I do not argue that victim empowerment should trump other ICJ objectives, such as promoting human rights, enforcing rule of law, and deterring future violence. The empowerment of victims to help address injustice should be seen as just one aim for ICJ, albeit an important one.

\section{I: Victim Powerlessness and Disempowerment: Three Critiques}

Claims about victims are increasingly central to debates about the legitimacy and purpose of international criminal justice in general and the ICC in particular. This attention to victims has come about for several reasons. ${ }^{9}$ In recent decades, victims' rights movements within states have promoted the participation of victims and the protection of their interests in domestic criminal justice systems. These campaigns have contributed to and borrowed from developments in international human rights law, as well as the decisions of international and regional human rights courts. Furthermore, international criminal justice processes are often considered a form of transitional justice, alongside processes such as truth commissions and memorialization efforts, and the field of transitional justice emphasizes victims' agency and recognition.

As a result of these and other developments, victims have become a 'figure' or a 'constituency' that is central to the legitimacy of international criminal justice. ${ }^{10}$ State diplomats, civil society advocates, the staff of international criminal tribunals, and other actors in the field frequently invoke victims and victimhood to gain authority, assistance and attention. In sum, one might say that victims - or at least the "imagined victims" of ICJ discourse ${ }^{11}$ - help to empower the field and

\footnotetext{
${ }^{8}$ Chris Tenove, 'Justice and Inclusion in Global Politics: Representing and Advocating for Victims of International Crimes.' Doctoral Dissertation, http://circle.ubc.ca/handle/2429/51982, University of British Columbia, Vancouver, 2015.

${ }^{9}$ See Stephen Smith Cody and Eric Stover, "The Role of Victims: Emerging Rights to Participation and Reparation in International Criminal Courts," in Philipp Kastner (ed.), International Criminal Law in Context, Routledge, London, 2017; Laurel E Fletcher and Harvey M Weinstein, "Transitional Justice and the 'Plight' of Victimhood," in Cheryl Lawther, et al. (eds.), Research Handbook on Transitional Justice, Edward Elgar Publishing, Cheltenham, UK, 2017; Luke Moffett, Justice for Victims before the International Criminal Court, Routledge, New York, 2014.

${ }^{10}$ Fletcher, 2016; Sara Kendall and Sarah Nouwen, "Representational Practices at the International Criminal Court: The Gap between Juridified and Abstract Victimhood," in Law \& Contemporary Problems, 2013, vol. 76, no. 3; Lohne, 2018; Frédéric Mégret, "In Whose Name? The ICC and the Search for Constituency," in Christian De Vos, et al. (eds.), Contested Justice: The Politics and Practice of International Criminal Court Interventions, Cambridge University Press, Cambridge, 2016.

${ }^{11}$ Fletcher, 2016.
} 
actors within it. ${ }^{12}$ However, some commentators argue that survivors of violence or repression are frequently disempowered by international criminal tribunals. Their concerns fit in three general categories: that victims status may expose people to harm; that victims' are powerless in ICJ processes and instrumentalized by other actors; and that the very social category of 'victim' in ICJ poses an obstacle to people's pursuit of the justice they desire. I will briefly examine those positions.

\section{Victims' vulnerability and risks of harm}

People may face risks to their wellbeing and their social relationships if they seek victim status from international criminal tribunals, and such harms may be disempowering. This concern has primarily been directed toward victim-witnesses, who may face intimidation, retribution, or social sanction from supporters of the people they testify against. Victim-witnesses may also experience re-traumatization or psychological strain when providing evidence to investigators or testifying in court. For instance, in interviews with victim-witnesses at the International Criminal Tribunal for the former Yugoslavia (ICTY), Mertus finds that they "almost universally experience the trials as dehumanizing and re-traumatizing experiences." 13

However, research on victim-witnesses paints a more complex picture. Based on interviews with larger samples of victim-witnesses at the ICTY than Mertus, Stover ${ }^{14}$ and more recently King and Meernik $^{15}$ find that while a significant number faced threats, social sanction, and insecurity after testifying, the majority did not. Furthermore, while some ICTY victim-witnesses attributed psychological harm to testifying, most do not. ${ }^{16}$ Indeed, research on victim-witnesses at the ICTY and at the Special Court for Sierra Leone suggests that engagement in trial processes can increase resilience and emotional wellbeing. ${ }^{17}$

Regarding the ICC, there are concerns that victim-witnesses are vulnerable to harm in some situations. As a glaring example, four female witnesses under the 'protection' of the ICC in the Democratic Republic of Congo (DRC) were subjected to sexual exploitation by an ICC staff

\footnotetext{
${ }^{12}$ For a further development of this argument see Dixon and Tenove, 2013.

${ }^{13}$ Mertus, 2004, p. 112.

${ }^{14}$ Eric Stover, The Witnesses: War Crimes and the Promise of Justice in the Hague, University of Pennsylvania Press, Philadelphia, 2005.

${ }^{15}$ Kimi Lynn King and James David Meernik, The Witness Experience: Testimony at the ICTY and Its Impact, Cambridge University Press, Cambridge, 2017.

${ }^{16}$ Stover, 2005; King and Meernik, 2017.

${ }^{17}$ Kimi Lynn King and James David Meernik, "The Burden of Bearing Witness: The Impact of Testifying at War Crimes Tribunals," in Journal of Conflict Resolution, 2017, vol. 0, no. 0; Shanee Stepakoff, et al., "The Experience of Testifying in a War-Crimes Tribunal in Sierra Leone," in Peace and Conflict: Journal of Peace Psychology, 2015, vol. 21, no. 3.
} 
member. ${ }^{18}$ Worries about victim-witness safety and witness tampering exist for many ICC cases. ${ }^{19}$ However, the most wide-ranging research on victim-witnesses at the ICC to date found most to be satisfied with the safety and security procedures. ${ }^{20}$

\section{Victims' powerlessness in ICJ processes and risks of instrumentalization}

Commentators and participants have argued that victims' roles in international criminal justice processes are overly-circumscribed and sometimes exploitive. From this perspective, victims' participation in judicial processes does not empower them to pursue justice but instrumentalizes them to support the aims of other actors.

The criticism that victims are "passive objects" rather than the active subjects of judicial processes has been directed most pointedly at earlier generations of tribunals. ${ }^{21}$ At the ad hoc tribunals created in the 1990s, prosecution and defense lawyers decided what opportunities victims would have to speak, often focusing on forensic details and submitting them to hostile cross-examination. Some of the most acute criticisms have focused on the role of female victims in trials. ${ }^{22}$

The ICC and other international tribunals created since the mid-1990s provide greater opportunities for victims to contribute to judicial processes, primarily as legal participants or parties. Victim legal participation has been heralded by some as a triumph of victim inclusion and dismissed by others as an exercise that is costly, provides little benefit to victims, or infringes on the due process of trials. ${ }^{23}$ Focusing on the victim participation at the ICC, some observers claim

${ }^{18}$ International Criminal Court, 'Public Report: Incident Review of Allegations of Sexual Assault of Four Victims under the Protection of the International Criminal Court in the Democratic Republic of Congo by a Staff Member of the Court.' http://www.icc-cpi.int/iccdocs/db/Registry-Figures-30-April-2013.pdf, 2013.

${ }^{19}$ Open Society Justice Initiative, "Witness Interference in Cases before the International Criminal Court," https://www.opensocietyfoundations.org/sites/default/files/factsheet-icc-witness-interference20161116.pdf, 2016.

${ }^{20}$ Stephen Smith Cody, et al., "Bearing Witness at the International Criminal Court: An Interview Survey of 109 Witnesses," Human Rights Center, University of California, Berkeley, 2014.

${ }^{21}$ Marie-Benedicte Dembour and Emily Haslam, "Silencing Hearings? Victim-Witnesses at War Crimes Trials," in European Journal of International Law, 2004, vol. 15; Claire Garbett, "From Passive Objects to Active Agents: A Comparative Study of Conceptions of Victim Identities at the ICTY and ICC," in Journal of Human Rights, 2016, vol. 15, no. 1.

${ }^{22}$ Susanne Buckley-Zistel, "Redressing Sexual Violence in Transitional Justice and the Labelling of Women as "Victims"," in Thorsten Bonacker and Christoph Safferling (eds.), Victims of International Crimes: An Interdisciplinary Discourse, T. M. C. Asser Press, 2013; Mertus, 2004; Gilbert Bitti, "Les Victimes Devant La Cour Pénale Internationale: Les Promesses Faites À Rome Ont-Elles Été Tenues?," in Revue de science criminelle et de droit pénal comparé, 2011, vol. 2.

${ }^{23}$ Emily Haslam and Rod Edmunds, "Victim Participation, Politics and the Construction of Victims at the International Criminal Court: Reflections on Proceedings in Banda and Jerbo," in Melbourne Journal of International Law, 2013, vol. 14, no. 2; Rachel Killean and Luke Moffett, "Victim Legal Representation before the ICC and ECCC," in Journal of International Criminal Justice, 2017, vol. 15, no. 4; Mariana Pena and Gaelle Carayon, "Is the ICC Making the Most of Victim Participation?," in International Journal of Transitional Justice, 2013, vol. 7, no. 3; Van den Wyngaert, 2012; Vasiliev, 2015. 
that victims do not substantively contribute to judicial processes, either directly or by giving instructions to a lawyer, and so victim 'participation' is more symbolic than real. ${ }^{24}$

\section{The displacement of survivor's agency and the cage of victimhood}

The most fundamental critique is that international criminal tribunals promote different forms of justice than those desired by survivors of mass violations, and that ICJ interferes in the actions that survivors themselves could take to pursue the justice they seek. As scholars observe, people with victim status are generally powerless to influence the aims and priorities of international criminal tribunals. Fletcher states that there is often tension between what "real" victims desire and the assumed desires of the "imagined victims" of ICJ discourse. ${ }^{25}$

The possible disjuncture between victims' aims for justice and the practice of international criminal tribunals is magnified by ICJ's European or Western pedigree, ${ }^{26}$ and by the disproportionate influence that powerful states have over the creation and conduct of tribunals. ${ }^{27}$ Nouwen and Werner suggest five alternatives to international criminal justice that may be displaced by the ICC's work. ${ }^{28}$ These include justice as resource redistribution and justice as the restoration of relationships. Furthermore, the very construction and mobilization of the social category of 'victims' can arguably be disempowering for survivors of violence and injustice. For instance, Branch contends that ICJ misinterprets political violence and forces actors into the illfitting roles of the "criminal," the "transcendent judge" and the "innocent, passive victims." 29 In the victim role, Branch argues, individuals are shunted into institutional processes and discursive framings that limit their abilities to pursue a more just political order.

Based on this and other concerns critiques, the empirical study that follows uses the term 'disempowerment' to mean that people's agency to pursue their aims (and in particular to address past or ongoing violence and injustice) is reduced in a durable fashion. 'Empowerment' means that people's agency is durably increased. ${ }^{30}$ This approach to empowerment has two major

${ }^{24}$ Emily Haslam and Rod Edmunds, "Common Legal Representation at the International Criminal Court: More Symbolic Than Real?," in International Criminal Law Review, 2012, vol. 12, no. 5; Kendall and Nouwen, 2013.

${ }^{25}$ Fletcher, 2016.

${ }^{26}$ Clarke, 2009; James G Stewart and Asad Kiyani, "The Ahistoricism of Legal Pluralism in International Criminal Law," in The American Journal of Comparative Law, 2017, vol. 65, no. 2.

${ }^{27}$ John Hagan, Ron Levi and Gabrielle Ferrales, "Swaying the Hand of Justice: The Internal and External Dynamics of Regime Change at the International Criminal Tribunal for the Former Yugoslavia," in Law \& Social Inquiry, 2006, vol. 31, no. 3; Mahmood Mamdani, "Responsibility to Protect or Right to Punish?," in Journal of Intervention and Statebuilding, 2010, vol. 4, no. 1.

${ }^{28}$ Sarah M.H. Nouwen and Wouter G. Werner, "Monopolizing Global Justice: International Criminal Law as Challenge to Human Diversity," in Journal of International Criminal Justice, 2015, vol. 13, no. 1.

${ }^{29}$ Branch, 2007, p. 190.

${ }^{30}$ For similar understandings of empowerment and agency, see Jay Drydyk, "Empowerment, Agency, and Power," in Journal of Global Ethics, 2013, vol. 9, no. 3; Erin K. Baines, "'Today, I Want to Speak out the Truth': Victim Agency, Responsibility, and Transitional Justice," in International Political Sociology, 2015, vol. 9, no. 4 . 
implications for empirical research. First, if empowerment refers to people's capacities to pursue their aims, an assessment of empowerment and disempowerment requires attention to their aims. Second, this approach highlights the interactions and ongoing relationships between relevant actors, such as survivors of mass rights abuses and staff of international criminal tribunals, and the structuring conditions or forces that shape those interactions.

\section{Context and Research Methods}

To interrogate these claims about victims' empowerment and disempowerment, I will turn to research with survivors of violence in Kenya and Uganda. In particular, I draw on 14 focus group discussions with 84 survivors of violence in seven different communities. ${ }^{31}$ Focus group participants were prompted to discuss why individuals might pursue recognition as victims by the ICC, the forms of justice that victims desire, and the role of the ICC in advancing or undermining justice for victims. The following analysis emphasizes the most commonly expressed views by discussants, but also includes alternative or dissenting views. The aim of this qualitative research was to explore people's experiences, perceptions, and understandings, in some depth. The proportion of individuals expressing different views cannot be assumed to be representative of survivors in the two countries. However, the perspectives advanced are consistent with published surveys of violence-affected communities in Kenya and Uganda. ${ }^{32}$

Focus group results are supplemented and contextualized by research conducted between 2010 and 2015 in Kenya, Uganda, New York and The Hague. In addition to participant observation, this research includes interviews with additional survivors of violence (four in Kenya, eight in Uganda), with members of 30 different civil society organizations that focus on victims' issues (12 in Kenya, 14 in Uganda and four in The Hague), and with over 50 individuals who worked as ICC staff, diplomats, and subject area experts.

\footnotetext{
${ }^{31}$ Focus groups were held in 2012, in four Kenyan communities that had experienced high rates of violence in 2007-2008 post-election violence, and three Ugandan communities that experienced extreme violence during the Ugandan civil war. Participants were purposively selected to gain the perspectives of individuals of different sexes (45 women and 39 men), ages, ethnicities and experiences of violence. All participants claimed to have been affected by crimes that are within the ICC's jurisdiction. Some had applied for or received victim participant status from the ICC. Semi-structured discussions were conducted in Lango, Luo or Swahili, and recordings were translated into English and analyzed. Discussions were facilitated to elicit people's observations, insights and normative judgements, rather than to simply register initial opinions.

For more details, including steps taken to avoid harm to participants and to fulfill requirements of the Behavioral Research and Ethics Board of the University of British Columbia, see Tenove, 2015.

32 These include Stephen Smith Cody, et al., "The Victims' Court?: A Study of 622 Victim Participants at the International Criminal Court," Human Rights Center, University of California, Berkeley, Berkeley, CA, 2015; ICJ and KHRC, "Elusive Justice: A Status Report on Victims of 2007-2008 Post-Election Violence in Kenya," International Commission of Jurists (Kenya) and the Kenya Human Rights Commission, Nairobi, 2012; Phuong Pham and Patrick Vinck, "Transitioning to Peace: A Population-Based Survey on Attitudes About Social Reconstruction and Justice in Northern Uganda," Human Rights Center, University of California, Berkeley, 2010.
} 


\section{Country cases}

Kenya and Uganda were chosen to explore the perspectives of survivors who experienced different types mass violence and different ICC interventions.

In Kenya, ICC Prosecutor Moreno Ocampo launched a formal investigation in 2009 regarding violence that occurred during and following the 2007 national election. During that period, there were ethnically-targeted killing, maiming, sexual violence, looting and property destruction, as well as widespread extrajudicial violence by police, which resulted in over 1,000 people deaths and an estimated 600,000 people forcibly displaced. ${ }^{33}$

In 2010 the Prosecutor named six accused persons, including Kenya's Deputy Prime Minister, Uhuru Kenyatta, and former cabinet ministers William Ruto. The ICC's work has been highly contested by the Kenyan government, particularly after two accused persons - Kenyatta and Ruto - joined forces and won the 2013 national elections. There have been accusations that possible witnesses for the prosecution were being intimidated or killed. ${ }^{34}$ Several key witnesses for the Prosecution recanted their testimony or refused to testify. The OTP failed to confirm charges against Ali and Kosgey in pre-trial hearings in 2012. Since the focus groups were conducted in 2012, the Prosecutor dropped charges against Muthaura in 2013 and Kenyatta in 2014, citing insufficient evidence. ${ }^{35}$ Trial judges terminated the case against Ruto and Sang in 2016 before the trial was completed, due to the weakness of the prosecution's evidence. ${ }^{36}$

In Uganda, the ICC became involved in 2003 when the Ugandan government referred to the Court the situation concerning the Lord's Resistance Army (LRA). The LRA had been fighting the Ugandan military since 1987 and had perpetrated mass killing, looting, abduction, and other forms of violence against civilians. Prosecutor Moreno Ocampo began investigations in early 2004 and in 2005 the ICC issued arrest warrants for LRA leader Joseph Konyand four of his commanders, including Dominic Ongwen. Two of the accused commanders have since died.

The ICC's role in Uganda received immediate support from international human rights NGOs and many states. However, ICC staff met a different reaction from activists and organizations on the ground in northern Uganda. ${ }^{37}$ Speaking on behalf of affected communities, they put forward three challenges to the assumption that victims would want or benefit from the ICC. First, many argued that the ICC's actions would undermine peace efforts, including amnesties and peace negotiations.

\footnotetext{
${ }^{33}$ Kenya National Commission on Human Rights, "On the Brink of the Precipice: A Human Rights Account of Kenya's Post-2007 Election Violence," Nairobi, Kenya, 2008.

${ }^{34}$ Gabrielle Lynch, "Non-Judicial Battles: Kenyan Politics and the International Criminal Court," Egmont, the Royal Institute for International Relations, Brussels, 2014.

${ }^{35}$ International Criminal Court Trial Chamber V(b), 'Prosecutor V. Uhuru Kenyatta: Notice of Withdrawal of the Charges against Uhuru Muigai Kenyatta.' ICC-01/09-02/11-983. December 5, 2014.

${ }^{36}$ International Criminal Court Trial Chamber V(a), 'Prosecutor V. William Ruto and Joshua Sang: Public Redacted Version of the Decision on Defence Applications for Judgments of Acquittal.' ICC-01/09-01/112027-Red-Corr. April 5, 2016.

${ }^{37}$ For accounts of local mobilization against the ICC's involvement, see Tim Allen, Trial Justice: The International Criminal Court and the Lord's Resistance Army, Zed, London, 2006; Branch, 2007.
} 
Kony repeatedly claimed that the ICC arrest warrants were a key obstacle to a peace deal. ${ }^{38}$ Second, many argued that the ICC's criminal justice approach differs from the local justice practices of many northern Ugandans, which often emphasize forgiveness and community reconciliation. Particular attention has been given to mato oput ceremonies and other practices of the Acholi people, the ethnic group that makes up the majority of the LRA's members and victims. ${ }^{39}$ Third, the Prosecutor's decision not to charge any members of the Ugandan government or military provoked a debate about the ICC's impartiality and allegations that it pursues selective justice. ${ }^{40}$ Critics argue that the Ugandan government has used the ICC as a tool to further stigmatize its opponents and to legitimize itself in the eyes of the international community. ${ }^{41}$

In 2015, former LRA commander Dominic Ongwen was captured and transferred to ICC custody. He has been charged with 70 counts of war crimes and crimes against humanity, including sexual and gender-based crimes, committed between 2002 and 2005. His trial began in December, 2016, and will continue through 2018. As of June 2018, 4107 victims had been granted the right to participate in proceedings. ${ }^{42}$

The following section summarizes key findings from focus group discussions in Ugandan and Kenyan communities.

\footnotetext{
${ }^{38}$ There is an ongoing debate among scholars about whether the ICC's intervention helped or hindered the peace process. See, among others, Michael Otim and Marieka Wierda, "Justice at Juba: International Obligations and Local Demands in Northern Uganda," in P. Clark and N. Waddell (eds.), Courting Conflict: Justice, Peace and the ICC in Africa, Royal African Society, 2008; Patrick Wegner, "Ambiguous Impacts: The Effects of the International Criminal Court Investigations in Northern Uganda," Refugee Law Project, Kampala, Uganda, 2012; Ronald R. Atkinson, "'The Realists in Juba'? An Analysis of the Juba Peace Talks," in Tim Allen and Koen Vlassenroot (eds.), The Lord's Resistance Army : Myth and Reality, Zed, London, 2010.

${ }^{39}$ On this debate see, among others, Tim Allen, "Bitter Roots: The 'Invention' of Acholi Traditional Justice," in Tim Allen and Koen Vlassenroot (eds.), The Lord's Resistance Army: Myth and Reality, Zed, London, 2010; Refugee Law Project, "Tradition in Transition: Drawing on the Old to Develop a New Jurisprudence for Dealing with Uganda's Legacy of Violence," Refugee Law Project, Makerere University, 2009.

${ }^{40}$ Academics and civil society groups have documented extensive violence by the Ugandan military during military actions and in the confinement of hundreds of thousands of northern Ugandans to displaced persons camps. See Lucy Hovil and Joanna Quinn, "Peace First, Justice Later: Traditional Justice in Northern Uganda," Refugee Law Project, Kampala, Uganda, 2005; Human Rights Watch, "Unfinished Business: Closing Gaps in the Selection of ICC Cases," Human Rights Watch, New York, 2011.

${ }^{41}$ Sarah M. H. Nouwen and Wouter G. Werner, "Doing Justice to the Political: The International Criminal Court in Uganda and Sudan," in European Journal of International Law, 2010, vol. 21, no. 4; Branch, 2007; Valerie Freeland, "Rebranding the State: Uganda's Strategic Use of the International Criminal Court," in Development and Change, 2015, vol. 46, no. 2.

${ }^{42}$ International Criminal Court, 'Case Information Sheet: Situation in Uganda, the Prosecutor V. Dominic Ongwen.' ICC-PIDS-CIS-UGA-02-013/18_Eng. June, 2018.
} 


\section{III: Survivors' Views of the ICC and Justice for Victims}

\section{The Significance of Victim Status}

When the ICC intervenes in a country, those who have suffered violence or rights abuses may pursue or resist victim status for a variety of reasons. Focus groups discussions and interviews in Kenya and Uganda revealed diverse and sometimes competing views about who the ICC should recognize as victims and what victim status should entail. Most saw the ICC as a critical arbiter of these decisions.

All Ugandan discussants and almost all Kenyan discussants agreed that the term 'victim' was appropriate for them, based on their experiences of violence and injustice. Many argued that to be recognized as a victim meant they had been harmed in the past and that there was a social obligation for others to help address the ongoing impacts of past harms.

When discussing these ongoing impacts, discussants frequently spoke of their disempowerment. Reduced agency often resulted from injuries and continuing health problems, psychological wounds, or material deprivation, which prevented people from pursuing social roles such as parent, worker, or active community member. Participants also identified the obstacles that victims face due to diminished social status. A Ugandan man who had been abducted by the LRA as a child explained that experience: "In homes and in schools there is a lot of stigmatization of those who were abducted. This situation leaves the returnees no choice but to isolate themselves from the community. We live in mimicry of our stay in captivity." 43

Many focus group participants saw victim status as a means to regain agency and active membership in their communities. For instance, a Kenyan man explained:

Because of the violence I suffered my life came to a standstill and my children continue to suffer, while I see others in my community who still have good lives... I don't have any problem with being called a victim. In fact, I feel freed when called a victim, because I will not be abandoned but I will be helped to forge a new life. ${ }^{44}$

The vast majority of Kenyan and Ugandan discussants hoped that victim status would prompt the Court to act on their behalves or help them pursue justice. Some discussants claimed that recognition as a victim by the ICC would lead to broader forms of recognition, assistance and understanding, from their governments, communities, or even their own families.

Given these and other expectations about the ICC's conferral of victim status, many focus group participants expressed concern that the ICC would inappropriately grant or withhold that status. For instance, both Kenyan and Ugandan participants argued that the temporal restrictions of the ICC investigations were problematic - as they excluded potential crimes committed before 2002 in Uganda (due to the temporal jurisdiction of the ICC), and before 2007 in Kenya. Focus group participants also criticized the particular cases that the Prosecutor pursued. For instance, many Ugandan discussants stated that people harmed by the Ugandan government and military warranted attention from the ICC as victims, and some claimed that the millions of Ugandans forced by the government into internal displacement camps should be recognized as victims.

\footnotetext{
${ }^{43}$ Male focus group participant, Palabek Kal, Lamwo District, Uganda.

${ }^{44}$ Male focus group participant, Vihiga County, Kenya.
} 
Because victim status entails normative recognition and possible material assistance, focus group participants in both countries worried that some people who were not 'real victims' would nevertheless be treated as deserving victims by the ICC. People often expressed concern that limited resources would be misdirected. This issue of 'real victims' was more politically fraught in Kenya, since when defendants in ICC cases positioned themselves as victims of the Court itself. A member of a Kenyan human rights organization explained, "Most of the suspects have begun to play the role of the victim. As civil society, what we have been trying to do is remind people who the real victims are - they are the people who suffered these different atrocities." ${ }^{45}$

\section{Interactions With the ICC}

The ICC does not simply act on or for victims, it creates contexts for people to act —including opportunities to seek victim status, provide information, articulate aims, and learn about the Court's actions and limitations.

One of the major innovations of the Rome Statute of the ICC is the opportunity for victims to be legal participants in judicial processes. This participation is primarily achieved via legal representation. The modalities of victim participation have differed across cases and situations, and is an ongoing matter of legal dispute. ${ }^{46}$ Victim representatives have informed judicial processes and outcomes in various ways. For instance, they have submitted motions, questioned witnesses, made opening and closing statements, and called victim participants to appear in court, and in doing so they have enriched trial records, have challenged the Prosecutor's selection of charges, and prompted judges to act on threats made against victims by supporters of accused persons. ${ }^{47}$ They have informed judges decisions to authorize the Prosecutor's to pursue investigations in Kenya and Côte d'Ivoire. ${ }^{48}$ Victims have also been consulted extensively regarding decisions to award and implement reparations. ${ }^{49}$ Despite the extensive commentary on victim participation, there has been relatively little analysis of its impact on trials or on victims themselves - in part because the ICC has only recently completed cases to the conclusion of all possible appeals. ${ }^{50}$

\footnotetext{
${ }^{45}$ Male interviewee, Nairobi, Kenya, August 2012.

${ }^{46}$ Pena and Carayon, 2013; Vasiliev, 2015.

${ }^{47}$ For the latter, see: International Criminal Court Pre-Trial Chamber II, 'Prosecutor V. William Ruto Et Al: Confirmation of Charges Hearing - Thursday, 8 September 2011.' 2011, 26-30.

${ }^{48}$ International Criminal Court Pre-Trial Chamber III, 'Decision Pursuant to Article 15 of the Rome Statute on the Authorization of an Investigation into the Situation in the Republic of Kenya.' 2010; International Criminal Court Pre-Trial Chamber III, 'Corrigendum to 'Decision Pursuant to Article 15 of the Rome Statute on the Authorisation of an Investigation into the Situation in the Republic of Côte d'Ivoire'.' 2011.

${ }^{49}$ See in particular International Criminal Court Registry, 'Prosecutor V. Katanga, 'Registry Report on Applications for Reparations in Accordance with Trial Chamber Ii's Order of 27 August 2014'.' ICC-01/0401/07-3512. Annex 1. December 15, 2014.

${ }^{50}$ But see Garbett ("The Truth and the Trial: Victim Participation, Restorative Justice, and the International Criminal Court," in Contemporary Justice Review, 2013, vol. 16, no. 2) on the Lubanga trial, as well as Haslam and Edmunds (2013) on the Jerbo and Banda trial.
} 
In interviews and focus group discussions, I asked Kenyan and Ugandan survivors described their understanding of potential contributions to ICC processes, and their hopes for how these interactions ought to take place. Three observations can be drawn from their responses: the Court can be an ambiguous and perplexing institution to engage; ongoing communication with the ICC was seen as critical for people to exercise agency; and survivors had quite different aspirations for their own interactions with the Court.

First, people's engagement with the ICC comes through interactions with a diverse and sometimes bewildering range of officials and go-betweens. These include staff from different units of the Court itself, national and international NGOs, and local intermediaries. Many of these individuals asked for information from survivors, and it was often unclear to individuals how their views were being used or whether they were informing the actions of the ICC itself. Interactions with these diverse representatives, officials and intermediaries generate a complex array of power dynamics and opportunities for agency for individuals who have or seek victim status. ${ }^{51}$ For some, the ongoing interactions with Court staff, NGO representatives, and researchers can generate fatigue and frustration, particularly when these interactions yield few tangible benefits and provide little new information about ICC developments.

Second, ongoing communication with ICC staff capable of providing substantive information was highly valued by discussants. ${ }^{52}$ Most discussants wanted to learn if and how the ICC was making progress on advancing justice aims. Many discussants suggested that they needed ongoing updates from the Court to identify how they could contribute to and derive benefits from the ICC's actions, often in the midst of evolving political and security contexts. They also wanted updates in order to evaluate changing risks to themselves for participating - or being perceived to participate - in ICC activities. Ongoing communication is thus important for the ICC's impact on the agency of victims, both positive and negative. Recognizing this, one ICC staff member who works with victims stated: "We want to be supported by victims, and in a perfect world they would be happy with what we do. But it's better to have well-informed victims who are pissed off at the Court than content victims who don't understand what is happening." 53

Third, survivors of violence did not all seek to engage with the Court in the same way. Among discussants in Kenya and Uganda, a significant minority claimed that their direct appearance at the Court was important, enabling them to advance justice for themselves and for fellow victims. As one Ugandan man argued: "I would like to tell the ICC everything I have seen...I [want] the ICC to pledge that it will use my testimony, because I know the next generation would reap the benefits when I am gone. ${ }^{54}$

A smaller category of focus group participants and interviewees wanted to make more extensive contributions, and argued that victims should contribute to the Court's policy-making as well as its judicial processes. They claimed that doing so would improve tribunals' outcomes for victims

\footnotetext{
${ }^{51}$ For a nuanced analysis of the role and power of intermediaries, see Leila Ullrich, "Beyond the 'GlobalLocal Divide': Local Intermediaries, Victims and the Justice Contestations of the International Criminal Court," in Journal of International Criminal Justice, 2016, vol. 14, no. 3.

${ }^{52}$ For a similar finding, see Cody, et al., 2015.

${ }^{53}$ Interview with ICC staff member, The Hague, September 2014.

${ }^{54}$ Male focus group discussant, Lukodi village, Gulu District, Uganda.
} 
and would enhance their social recognition. Along these lines, a member of an association of Ugandan women affected by civil war stated:

We want to show the world that survivors or victims are the ones who know their problems best and who can advocate for justice better than a sympathizer or someone who knows about them. At the end of it all, justice is a process of our empowerment rather than the outcome of justice done. ${ }^{55}$

However, the largest category of focus group discussants and interviewees wished to make more modest contributions by sharing their views and experiences in private and secure interactions with Court staff. ${ }^{56}$ Furthermore, many discussants claimed that the quality of their representation was at least as important as direct participation. In addition to security risks associated with direct participation, some claimed that victims' interests should be advanced by individuals with appropriate expertise, including but not limited to lawyers. Taken together, these responses suggest that direct participation and victims" "visibility" in the courtroom should not be seen as the ideal of victim engagement, but rather as one of a range of forms of desirable engagement.

\section{Multiple Forms of Justice for Victims}

For the ICC to empower survivors of mass violence and rights abuses, it must create durable improvements in people's opportunities to advance the justice that they desire. To assess those possibilities, discussions in Kenya and Uganda addressed the forms of justice and the opportunities for justice that survivors hoped the ICC would advance. They also identified possibilities for disempowerment.

\section{Justice as accountability}

The ICC was created to hold individuals to account for war crimes, crimes against humanity, genocide and aggression. In focus groups and interviews, almost all survivors of violence agreed that the ICC should investigate those who were most responsible for ordering or orchestrating mass violence. ${ }^{57}$ However, there was some variation in discussants' views on the contribution that accountability might bring to victims' pursuit of justice, and the possibilities for disempowerment that might result from the ICC's pursuit of accountability.

Discussants and interviewees put forward different normative justifications and different aims for pursuing accountability. The trial and punishment of individual perpetrators was seen to serve instrumental and intrinsic justice aims. For instance, as a Ugandan woman said:

\footnotetext{
${ }^{55}$ Interviewee, Gulu District, Uganda, June 2012.

${ }^{56}$ For a similar finding, see Cody, et al., 2015, p. 32-33.

${ }^{57}$ This finding differs from some previous accounts, which suggest less local support for ICC prosecutions in Uganda (see, for e.g., Hovil and Quinn, 2005; Pham and Vinck, 2010). Several factors may explain my different findings. First, the security situation in northern Uganda was much better than during the time of these earlier reports, so participants were less concerned that the ICC's actions would prompt LRA attacks or undermine a peace process. Second, some discussants who initially disagreed with ICC prosecutions changed their position during the course of discussions, once they understood that prosecutions would be limited to a few top leaders. Third, my focus groups are a small sample and may not be representative of affected communities more broadly.
} 
I was very impressed when I heard that the ICC will investigate, try and punish those commanders, so that we do not need to fear these deliberate killings again. I am very happy that those who killed my people are finally going to be punished and my dead ones will get their justice. ${ }^{58}$

Many discussants argued that accountability enforced by the ICC could help reconstruct a social order that was torn during conflict and that remains frayed. As a Ugandan man stated, "The undisciplined man who thinks he is above the law should be disciplined and corrected, he should be pruned by the ICC. Then he will understand the law and respect others." ${ }^{59}$ As this man and other discussants argued, the reconstruction of social order would help affirm the value of people who were harmed.

Most focus group participants in Kenya and Uganda claimed that the ICC - and not domestic courts - should pursue accountability against powerful individuals. Many expressed skepticism about the fairness and effectiveness of their domestic judicial systems. As a Kenyan man stated, "I am happy that this court was created to try the 'big fish' that can't be tried in their own countries because of their influence and power... But the ICC is very strict on the law. If you are found guilty there is no short cut, you have to pay for it." $" 60$

However, discussants raised concerns about how the ICC's capacity to pursue meaningful and just accountability.

One concern was that the ICC's focus on criminal accountability would preclude local or traditional justice processes - in other words, that it would disempower people's ability to pursue more appropriate forms of justice. However, this concern was raised by a small minority of Ugandan discussants and by no Kenyan discussants. Many Ugandan discussants were broadly supportive of local justice processes such as mato oput for low-ranked LRA militants, particularly those abducted as children, but they saw ICC accountability measures as more appropriate for LRA commanders and for senior Ugandan military or government officials.

More controversial than the tension between local justice and international criminal justice was the question about who would be held to account and for what actions. The ICC only focuses on a subset of crimes by a limited number of individuals in any situation. To a significant extent the Prosecutor makes these decisions. Like many experts, ${ }^{61}$ discussants raised concerns about gaps in the charges put forth by the prosecutor. Many discussants criticized the ICC's failure to bring charges against top leaders in the Ugandan government and military. ${ }^{62}$ When discussing this issue, there was considerable blurring between legal accountability for crimes and political accountability for leaders' decisions and their consequences. For instance, those who wanted ICC

\footnotetext{
${ }^{58}$ Female focus group discussant, Lukodi village, Gulu District, Uganda.

${ }^{59}$ Male focus group discussant, Lukodi village, Gulu District, Uganda.

${ }^{60}$ Focus group discussant, Vihiga County, Kenya.

${ }^{61}$ For analysis of prosecutorial discretion see, among others, Nouwen and Werner, 2010; William Schabas, "Victor's Justice: Selecting Situations at the International Criminal Court," in The John Marshall Law Review, 2009, vol. 43; Alana Tiemessen, "The International Criminal Court and the Politics of Prosecutions," in The International Journal of Human Rights, 2014, vol. 18, no. 4-5.

${ }^{62}$ This criticism of the ICC by many northern Ugandans has been widely documented. See, for example, Cody, et al., 2015; Hovil and Quinn, 2005; Human Rights Watch, 2011.
} 
trials of Ugandan President Museveni or former Kenyan President Mwai Kibaki often claimed that as leaders they were responsible for the context in which crimes occurred, sometimes likening them to the heads of households who should bear responsibility for all the actions of their 'children' or subordinates.

Discussants not only raised concerns about the fairness of ICC selectivity, they also explained ways in which this selectivity might undermine the pursuit of justice by people harmed by mass violence. Several discussants suggested that the ICC's failure to charge powerful individuals - and especially those in the Ugandan government or military - would help to "hide" those crimes and "protect" their perpetrators from national processes of legal or political accountability. Many argued that if the ICC failed to hold accountable leaders on "all sides" of a conflict, the Court would in effect be denying the violence and injustice that many people experienced.

\section{Justice as truth and recognition}

Experts and practitioners disagree about the extent to which the ICC might operate as a mechanism of public truth-telling, since criminal trials pursue narrow and perpetrator-oriented inquiries. ${ }^{63}$ Focus group discussants and interviewees frequently saw the ICC as playing two important roles for public truth-telling: seeking truth and promoting the recognition of truth.

The first truth-telling role derives from the ICC's capacity to investigate and provide information that victims desire. For instance, victims may seek a court's assistance to identify what happened to a loved one who is missing or deceased, or to better understand the actions and motivations of perpetrators. Several respondents stated that they hoped the ICC would help them find out how and why crimes occurred.

However, this was not the 'truth-telling' that most discussants looked for. Instead, they wanted their own views, and accounts of past and ongoing injustice, to be heard and acknowledged. For this role, the Court would not simply pursue truth on behalf of victims but would help amplify and validate the truths of victims.

For instance, a Kenyan woman argued that the ICC could make community members understand what she suffered, and could also force the Kenyan government to acknowledge the existence of victims. She stated: "The ICC had to come because Kenya was not willing to tell the truth about the post-election violence." ${ }^{\prime 4}$ Like many discussants, she wanted the ICC's truth-telling to remind other responsible actors of their social obligations to redress victims' ongoing suffering.

The desire by victims to have their truths known and acknowledged can be seen as the justice aim of recognition. For this to occur, people must believe that their voices, experiences or identity are represented in a symbolically significant process, and acknowledged by the appropriate audience. ${ }^{65}$ Different respondents identified different intended audiences for this truth-telling, from fellow

${ }^{63}$ Garbett, 2013; Barrie Sander, "Unveiling the Historical Function of International Criminal Courts: Between Adjudicative and Sociopolitical Justice," in International Journal of Transitional Justice, 2018, vol. 12 , no. 2 .

${ }^{64}$ Focus group discussant, Ugunja, Siaya County, Kenya.

${ }^{65}$ Peter Dixon, "Reparations and the Politics of Recognition," in Carsten Stahn, et al. (eds.), Contested Justice: The Politics and Practice of International Criminal Court Interventions, Cambridge University Press, Cambridge, 2016. 
community members to fellow nationals to a world community. For example, several Kenyan discussants claimed that they needed the ICC to make their national government recognize victims and act on their plight. In contrast, a Ugandan man explained why he would like to speak at the ICC about the LRA attack on his village and its impact: "To me I think that our story should be told to the whole world... That way, when other voices cry out again in the future, they may get attention." $" 66$

Discussants also identified ways that the ICC might obstruct opportunities to contribute to public truth-telling. One risk was that the Court would not grant victim status to the appropriate people, perhaps because the harms they experienced were not pursued in cases or those cases collapsed. Another risk was that their communication with the ICC could prompt the supporters of accused persons to seek to violently silence them. These concerns were more frequently raised in Kenya, where many discussants believed that lending their voices to the Court would be seen as a provocation by the government or by powerful supporters of accused persons. As one man put it, "There is risk because whenever you speak the truth, some people will definitely be offended and this may put your life in danger." 67

Compared to previous international criminal tribunals, the ICC offers greater opportunities for victims to contribute their perspectives to trials. As will be discussed in greater detail below, they can do so through legal representation, by appearing as prosecution or defense witnesses, and more rarely - as witnesses called by victims' lawyers. However, a small number of discussants felt that the ICC used them as an information resource rather than amplifying their voices. They stated that they felt powerless in their relationships with the staff of the ICC and affiliated NGOs, who came to question and collect statements from survivors, but provided little in return and offered little control over how this information would be used or the impact it might have.

\section{Justice as reparation}

Survivors of conflict frequently place greater emphasis on victim reparation than perpetrator accountability. ${ }^{68}$ Unlike earlier international criminal tribunals, the ICC provides victims with actionable rights to reparation, as well as possible measures of rehabilitation and assistance from an affiliated body, the Trust Fund for Victims (TFV). Discussants in Kenya and Uganda frequently argued that prosecutions alone would not provide justice, because victims would continue to suffer the physical, psychological, economic and social consequences of past injustices. Many focus group participants and interviewees stated that they pursued victim status out of a desire for some form of reparations or assistance. ${ }^{69}$

Most discussants claimed that their own governments held primary responsibility for reparative measures, but suggested that the ICC ought to intervene in the breach of those responsibilities. These calls for reparative justice fell into two general categories: communal and individual.

\footnotetext{
${ }^{66}$ Focus group discussant, Lukodi village, Gulu District, Uganda.

${ }^{67}$ Focus group discussant, Vihiga County, Kenya.

${ }^{68}$ See, for example, Pham and Vinck, 2010; Harvey M. Weinstein, et al., "Stay the Hand of Justice: Whose Priorities Take Priority?," in Roland Shaw, et al. (eds.), Localising Transitional Justice: Interventions and Priorities after Mass Violence, Stanford University Press, Stanford, 2010; Fletcher, 2016.

${ }^{69}$ For a similar finding, see Cody, et al., 2015.
} 
Many Ugandan participants called for compensation and other reparative measures to assist their communities or the entire northern region of Uganda. This position was justified by pointing to the lasting effects of conflict. As one man explained, these lasting effects include high rates of hunger, illness and economic deprivation, and he declared: "Honestly, the war has not ended; we have only rested from the sound of gunshots." 70 This respondent and others called for collective reparations to the legacy of the civil war and the systemic inequalities among regions in Uganda due to state policies.

The second category of reparative justice is individual-level rehabilitation, compensation, and assistance. The majority of Kenyan and Ugandan respondents claimed that these were needed to address ongoing injustices, which were the undeserved poverty, disability or social marginalization that resulted from past harms. In the words of one Kenyan interviewee, "It is not justice for me that the perpetrator is punished, while I continue to be punished by the poverty that came from the attack on our household."71

Some discussants claimed that the ongoing effects of past harms were undermining their capacity to themselves pursue justice. For instance, a Ugandan woman, speaking of former LRA abductees like herself, said that because of stigmatization, "We are unable to speak and act for ourselves." 72 A Kenyan man who had unhealed bullet wounds said: "I cannot work or even lobby officials of the government because of my injuries, and I cannot get treatment without money or help from the government. To get out of this trap would be justice for me."73

Reparative measures did prompt some concerns. Discussants raised the possibility of acrimonious competition for victim status when people believe that a direct material benefit would result, as well as the possibility that individuals who receive reparations might become the objects of envy and stigma in their communities. ${ }^{74}$ However, the most common concern was that reparative measures would be severely delayed or would not come at all. Indeed, by 2018 no reparation orders have been issued by the Court in the Kenya or Uganda situations, since there have been no completed cases or convictions. The TFV can provide assistance before a conviction is achieved. However, it did not operate in Kenya, to the frustration of some victims and their allies. The TFV has funded projects in Uganda since 2008. An independent study of TFV programs in Uganda and the DRC found that recipients credited the medical, psychological and material support they received with helping them "to live a normal life again, to make plans for the future, to resume school and work, [and to gain] the confidence to participate in community gatherings again."75

More empirical research is required in order to further explore the impact of TFV, and in particular to assess the impact of ICC reparations (and their denial) on people who pursued victim status.

\footnotetext{
${ }^{70}$ Male focus group discussant, Lukodi village, Gulu District, Uganda.

${ }^{71}$ Female interviewee, Eldoret, Uasin Gishu County, Kenya.

${ }^{72}$ Focus group discussant, Palabek Kal, Lamwo District, Uganda.

${ }^{73}$ Focus group discussant, Vihiga County, Kenya.

${ }^{74}$ See also Dixon, 2016.

75 Jennifer McCleary-Sills and Stella Mukasa, "External Evaluation of the Trust Fund for Victims Programmes in Northern Uganda and the Democratic Republic of Congo: Towards a Perspective for Upcoming Interventions," International Center for Research on Women, The Hague, 2013, p. 8.
} 


\section{Improving political opportunities for justice}

In addition to more familiar justice aims in international criminal justice, including accountability, truth and reparations, discussants in Kenya and Uganda also argued that the ICC could create opportunities for victims and their allies to more effectively pursue justice via other institutions or political processes. To use a sociological term, they suggested that the ICC could improve - or undermine - the political opportunity structure for them to act. ${ }^{76}$

One aspect of political opportunity structure that discussants highlighted was agenda-setting. The ICC, they claimed, could provoke greater public attention to past crimes or injustices, and amplify victims' demands for redress and political reform. For instance, a Ugandan man said, "I think the ICC has opened the eyes of government, which tried to stay blind to the atrocities that had happened here in Barlonyo," and he argued that the resulting pressure from local and international activists caused state officials to pay attention and provide some compensation. ${ }^{77}$ In Kenya, a member of a human rights organization argued: "If we didn't have the ICC there wouldn't be as much discourse in the public arena about the post-election violence ... [ans issues such as] forced disappearances, police brutality, and overall the lack of accountability of our political leaders." 78

Second, survivors and affiliated civil society groups saw the ICC as helping them gain access to new allies and resources. Several discussants described how meetings that were facilitated by ICC staff led to new relationships with fellow survivors, local community leaders, or national civil society organizations. For instance, a Kenya man said that he feared to speak of his victimization in his community, but in ICC-brokered meetings with fellow victims he felt free to talk: "It brings me relief to speak to other victims about the problems I face." $" 79$

In addition, members of local civil society groups described new opportunities to work with international organizations and NGOs to push for accountability and victim recognition. ${ }^{80}$ These opportunities included public advocacy campaigns and human rights litigation in domestic courts, in addition to work focused on ICC processes. ${ }^{81}$ However, respondents also spoke of risks that these relationships might distract them from doing work that would best benefit survivors of mass violence. For example, civil society members in Kenya spoke of an international donor "market" for victims of the 2007-8 post-election violence, and claimed that it had become harder to get funding for projects that assisted people harmed by mass violence that was not being investigated by the ICC. Furthermore, some civil society groups in Kenya foresaw and later experienced a backlash from the government for their support of the ICC.

Finally, discussants suggested that the ICC's intervention had somewhat lessened their fears of violence and repression, and the fears of their allies. According to many Kenyan focus group

\footnotetext{
${ }^{76}$ On the concept of 'political opportunity structures,' see for instance, Charles Tilly and Sidney G Tarrow, Contentious Politics, Oxford University Press, Oxford, 2015.

${ }^{77}$ Focus group discussant, Barlonyo village, Lira District, Uganda.

${ }^{78}$ Interview in Nairobi, Kenya, August 2012.

${ }^{79}$ Interviewee, Ugunja, Siaya County, Kenya, 2012.

${ }^{80}$ Interviews with members of civil society organizations in Gulu and Lira districts, Uganda (2011 and 2012) and in Eldoret, Kisumu and Nairobi in Kenya (2012).

${ }^{81}$ Tenove, 2015.
} 
participants, the principle impact of the ICC had been the reduction in risks of politically-motivated violence among competing ethnic factions. As one Kenyan woman said, "The ICC has done a good thing by summoning the suspects of the post-election violence before the court. If they didn't do that, we could still be at war." 82 Many Ugandan discussants credited the ICC with scaring off the LRA and improving the behavior of their government. Some civil society actors suggested that Kenyan and Ugandan politicians were more respectful of peace and human rights due to the ICC's ongoing monitoring of events in the countries, though others disagreed. ${ }^{83}$

Evidence to support these claims is mixed. In Kenya, the elections in 2013 and 2017 were much less violent than in 2007, but it is unclear whether the ICC's involvement played a significant role. Certainly, the ICC offers no certitude of declining violence, as is clear from ongoing conflict in the CAR, DRC and Libya. Regarding Uganda, the ICC's impact on the civil war with the LRA is mixed, ${ }^{84}$ and so too is its impact on violence and repression by the Ugandan state. ${ }^{85}$

\section{IV: Selective, Channeled and Contextual Effects on Agency}

Survivors of violence in Kenya and Uganda described how they may seek, compete over, utilize and become frustrated by victim status granted by the ICC. They articulated different and sometimes contrasting aspirations for the role the Court might play in helping them attain justice, and they often had desires that exceed the Court's current capacities. Drawing on this research and secondary literature, I argue that international criminal tribunals may enhance the agency of some victims to pursue some aims in some contexts, while undermining that agency in other situations. More specifically, I propose that this variability exists because tribunals are highly selective about who receives victim status, they channel people's agency in specific ways, and their effects are highly context-dependent rather than being consistent over time and across situations.

\section{Selective}

When people are recognized as victims by international criminal tribunals, they may gain opportunities to contribute to judicial processes or to receive reparations from them. Victim status may also generate benefits such as social recognition of the past and ongoing injustices that people face. For this reason, the fact that international criminal tribunals grant formal victim status to a very limited number of people can be a cause for anger and frustration. ${ }^{86}$ Survivors who seek

\footnotetext{
${ }^{82}$ Female focus group discussant, Ugunja, Siaya County, Kenya.

${ }^{83}$ Interviews with members of civil society organizations in Kampala and Gulu District (2012), and in Kisumu and Nairobi in Kenya (2012).

${ }^{84}$ Atkinson, 2010; Otim and Wierda, 2008; Wegner, 2012.

85 Valérie Arnould, "Transitional Justice and Democracy in Uganda: Between Impetus and Instrumentalisation," in Journal of Eastern African Studies, 2015, vol. 9, no. 3.

${ }^{86}$ For similar findings with respect to the ICC, see Cody, et al., 2015; Dixon, 2016. For similar findings at the ECCC, see Rachel Killean, "Constructing Victimhood at the Khmer Rouge Tribunal: Visibility, Selectivity and Participation," in International Review of Victimology, 2018, vol. 24, no. 3.
} 
victim status but do not receive it often interpret the decision as a denial of the injustice they experienced and the removal of an opportunity to advance justice.

This selectivity regarding victim status is a particularly acute problem for international criminal tribunals, compared to other transitional justice mechanisms (such as truth commissions) or to conventional criminal processes. Not all acts of violence are international crimes, and not all international crimes will be pursued by international criminal tribunals. Jurisdictional limitations significantly narrow the situations and crimes that tribunals can investigate. The mandates and limited resources of tribunals further limit the number and scope of cases they pursue, primarily by shaping prosecutors' decisions. ${ }^{87}$ Aptel therefore likens international criminal prosecutors to film directors, since they shine the "spotlight" of international criminal justice on some acts "and leave everything else in the dark." 88 The spotlight often becomes smaller still during judicial proceedings as charges are dropped or accused persons acquitted. In many countries where the ICC has intervened, the tribunals' "spotlight" has progressively narrowed from the initial intervention through to the end - or collapse - of judicial proceedings, thus generating an arc of increasing disappointment among survivors of violence.

This pattern is clear in the Kenyan situation. The prosecutor's failure to pursue charges against some crimes and some leaders, including Kenyan opposition leader Raila Odinga, provoked distress and criticism by some survivors of violence. The ICC's spotlight narrowed further as the Prosecutor failed to advance cases in pre-trial confirmation of charges hearings and then in trials. By 2016, all cases had collapsed and the spotlight went dark.

The lawyer for victims' in the case against Kenyatta solicited the views of those he represented after the case collapsed, and described their feelings of anger, betrayal and disbelief to the judges. He concluded:

Nearly seven years after the crimes and after three years of proceedings, the victims in this case have received no truth, accountability or reparation from the Court. Nor have they received any 'general assistance', which falls within the mandate of the Trust Fund for Victims. In short, they have received almost nothing from the entire ICC process. ${ }^{89}$

In Uganda, the Prosecutor's decision not to advance charges against President Museveni and other senior government or military officials has provoked frustration and has limited opportunities for some survivors to pursue justice. So, too, has the Court's inability for more than a decade to secure accused persons after arrest warrants were issued. However, once Ongwen was turned over to the ICC in 2015, the Prosecutor somewhat widened the spotlight of attention. Based on additional investigations, the Prosecutor substantially expanded upon the charges against Ongwen that existed in the original arrest warrant, to address attacks on additional communities and additional thematic offenses such as sexual and gender-based crimes. Victims' lawyers praised these

\footnotetext{
${ }^{87}$ For analysis of prosecutorial discretion see, among others, Nouwen and Werner, 2010; Schabas, 2009; Tiemessen, 2014.

${ }^{88}$ Cécile Aptel, "Prosecutorial Discretion at the ICC and Victims' Right to Remedy: Narrowing the Impunity Gap," in Journal of International Criminal Justice, 2012, vol. 10, no. 5, p. 1372

${ }^{89}$ International Criminal Court Trial Chamber V(b), 'Prosecutor V. Uhuru Kenyatta: Victims' Response to the 'Prosecution's Notice of Withdrawal of the Charges against Uhuru Muigai Kenyatta'.' ICC-01/0902/11-984. December 9, 2014, p. 18
} 
developments, though they continued to argue that important acts of victimization had been left out. ${ }^{90}$

The selective conferral of victim status by international criminal tribunals can be an obstacle for some people to pursue justice aims. It can create conflicts and cleavages within communities, thereby undermining collective action to pursue justice. ${ }^{91}$ Social cleavages can arise from the selection of cases to prosecute, but also from the distribution of reparations. The selection of some individuals to receive reparations can expose them to resentment and community backlash, particularly if they belong to stigmatized categories such as former child soldiers and victims of sexual violence..$^{2}$

Finally, the selectivity of international criminal tribunals may sometimes help to justify crimes and protect the reputations of those actors who are not prosecuted. ${ }^{93}$ In such situations, some survivors may face challenges including a poorer political opportunity structure for their pursuit of justice.

\section{Channeled}

International criminal tribunals, like all institutions, bring people into sets of structured relationships with others. These structured relationships expose people to tribunals' power over them, as well as opportunities to exercise agency in alignment with tribunals. In doing so, tribunals shape victims' opportunities for action and the aims they may pursue. I call this the channeling of agency.

Because agency is channeled, individuals designated as victims may be empowered for some justice projects and undermined for others. Like travellers in a boat in a water channel, survivors find that their movement becomes easier if they are going the direction of the canal and more difficult if they wish to go elsewhere. This channeling is revealed in the gaps between the forms of justice that the ICC may promote and the justice aims of some survivors. These gaps may be large - such as when survivors wish that tribunals will help rebuild communities - or smaller, such as when survivors pursue broader truth-telling from tribunals than criminal processes allow.

The channeling of agency can also be seen in the forms of action that international criminal tribunals offer to people with victim status. Those who wish to be victim participants experience this channeling from the moment that they meet ICC staff or civil society affiliates, and are asked to contribute information about some forms of injustice they suffered and not others. Those

\footnotetext{
${ }^{90}$ International Criminal Court Pre-Trial Chamber II, 'Prosecutor V. Dominic Ongwen - Monday, 25 January 2016.' 2016, p. 5-9, 37-38.

91 This argument was repeatedly made by Kenyan focus group discussants in my research. Survivors declared that the failure of the ICC to pursue crimes against "all sides" of the past electoral violence including the two leading candidates for president in 2007 - meant that the Court exacerbated rather than overcame political conflict. and distracted from a national pursuit of justice for victims. For similar arguments in other country cases, see Tami Amanda Jacoby, "A Theory of Victimhood: Politics, Conflict and the Construction of Victim-Based Identity," in Millennium - Journal of International Studies, 2015, vol. 43 , no. 2.

${ }^{92}$ Dixon, 2016.

${ }^{93}$ For this argument in the case of Uganda, see Branch, 2007; Freeland, 2015. More ICC cases beyond Uganda see Nouwen and Werner, 2010; Tiemessen, 2014.
} 
individuals who can provide evidence for proving crimes may be put in contact with the Prosecutor and potentially become witnesses (giving them 'dual status' in proceedings as witnesses and as participating victims), while others might provide compelling illustrations of the harms victims endured and their impacts: either in the courtroom or - more often - via their legal representative. By contrast, those who wish to pursue other activities, such as testifying to forms of structural violence, or directing investigators to seek missing relatives, will find the ICC unhelpful. Survivors also have no opportunities to pursue justice on their own timelines.

Victim representation in ICC cases in Kenya and Uganda reveals a range of contributions that survivors may make. In Kenya, there were ultimately almost 1,800 victim participants in the two cases that went to trial. Before the cases were terminated, their representatives had made statements, legal submissions, and questioned witnesses in both pre-trial and trial proceedings. Lawyers for the victims also consulted their clients to inform policy decisions. For instance, when the Trial Chamber contemplated holding trials in Nairobi or Arusha rather than The Hague and communicated their views: over 97\%, wanted trials to remain in The Hague, out of concerns that accused persons could more effectively influence trials held in Kenya or East Africa. ${ }^{94}$ Importantly, victims' lawyers were able to communicate with some regularity with the people they represented, either in person, through local staff, or by phone.

In Uganda, at the time of writing this chapter, over 4,000 individuals have registered to participate as victims in the trial against Ongwen. They are represented by two legal teams. ${ }^{95}$ In addition to legal submissions, statements and questions of witnesses, the victims' lawyers have been able to call their own witnesses to speak to the ongoing impact of the alleged crimes. These witnesses included three expert witnesses and two community leaders from two of the communities that were attacked. While victims' lawyers have not been able to further expand the charges laid, they have been able to raise concerns about other victims and accusations of the Ugandan governments' responsibility for injustice. ${ }^{96}$

The relationship between victims and their legal representative is a key structuring of the agency of victims, and one over which the tribunal has significant control. ${ }^{97}$ So, too, are relationships with local intermediaries and with ICC staff. In all these relationships, most victims have fewer material, social, and dispositional resources than their interlocutors, and thus have very limited opportunities to set the rules and aims of interactions. ${ }^{98}$

\footnotetext{
${ }^{94}$ International Criminal Court Trial Chamber V, 'Prosecutor V. Francis Muthaura and Uhuru Kenyatta: Victims' Observations in Relation to the 'Defence Application for Change of Place Where the Court Shall Sit for Trial'.' 2013.

${ }^{95}$ For analysis of the tensions that led to the creation of the two teams, see Michael Adams, "Who Will Stand for Us?: Victims' Legal Representation at the ICC in the Ongwen Case and Beyond," Human Rights Watch, New York, 2017.

${ }^{96}$ See, for instance, International Criminal Court Pre-Trial Chamber II, 'Prosecutor V. Dominic Ongwen: Victims' Pre-Confirmation Brief.' ICC-02/04-01/15. January 18, 2016, p. 19.

${ }^{97}$ For arguments over the responsiveness of victim legal representatives to the tribunal or to their 'clients,' see Haslam and Edmunds, 2013; Emily Haslam and Rod Edmunds, "Whose Number Is It Anyway? Common Legal Representation, Consultations and the 'Statistical Victim'," in Journal of International Criminal Justice, 2017, vol. 15, no. 5; Pena and Carayon, 2013.

${ }^{98}$ For a development of this argument, see Dixon and Tenove, 2013, p. 408-411.
} 


\section{Context-dependent}

International criminal tribunals operate in very diverse contexts. They may or may not be located in the country where crimes under consideration occurred; they may or may not have the backing of the UN Security Council or powerful states; and - perhaps most importantly - they may face a supportive or a hostile national government in the country where crimes occurred. Different contexts influence tribunals' behaviors and outcomes, such as prosecutorial strategy and arrests secured, ${ }^{99}$ local legitimacy, ${ }^{100}$ and the deterrence of further conflict or rights abuses in the country under consideration. ${ }^{101}$ Less attention has been given to the impact that context has on empowering or disempowering survivors' pursuits of justice. Nevertheless, several patterns are clear.

First, cultural understandings of victimhood and the forms of justice that victims desire vary across and within societies. ${ }^{102}$ For instance, notions of collective victimhood - and collective responsibility for victimhood - are prominent among the Acholi people in northern Uganda, and lead to different expectations of justice for victims than are common in countries such as Kenya, Bosnia, or the United States. The ICC's criminal-legal approach to justice will thus resonate more powerfully with survivors in some contexts compared to others.

Second, international criminal tribunals usually intervene in situations where national governments are unable or unwilling to pursue justice. Indeed, research by me and others suggests that survivors of violence frequently support the ICC because they distrust domestic institutions. However, the ICC and other tribunals struggle to investigate, make arrests and achieve convictions when domestic governments are hostile to their activities. While convictions do not necessarily advance all survivors' justice aims, they are necessary for at least some individuals to see meaningful accountability or truth-telling, or to receive court-ordered reparations.

Third, the security situation in which tribunals operate can shape survivors' aims and the risks faced by people granted victim status. For instance, Ugandans were exposed to both LRA attacks and harmful Ugandan government responses during the early years of the ICC's intervention. During this period, survivors were frequently concerned that they might face retributions from the LRA for engaging with Court staff. ${ }^{103}$ As the security situation improved and people moved from displacement camps in northern Uganda to their communities, individuals focused more on the

${ }^{99}$ Hagan, Levi and Ferrales, 2006; Eric Stover, Victor Peskin and Alexa Koenig, Hiding in Plain Sight: The Pursuit of War Criminals from Nuremberg to the War on Terror, University of California Press, Oakland, CA, 2016; Tiemessen, 2014.

${ }^{100}$ Laurel E Fletcher, Harvey M Weinstein and Jamie Rowen, "Context, Timing and the Dynamics of Transitional Justice: A Historical Perspective," in Human Rights Quarterly, 2009, vol. 31, no. 1; Jelena Subotic, "Truth, Justice, and Reconciliation on the Ground: Normative Divergence in the Western Balkans," in Journal of International Relations and Development, 2015, vol. 18, no. 3.

101 Hyeran Jo and Beth A. Simmons, "Can the International Criminal Court Deter Atrocity?," in International Organization, 2016, vol. 70, no. 3 Geoff Dancy and Eric Wiebelhaus-Brahm, "The Impact of Criminal Prosecutions During Intrastate Conflict," in Journal of Peace Research, 2018, vol. 55, no. 1.

102 Jan Van Dijk, "Free the Victim: A Critique of the Western Conception of Victimhood," in International Review of Victimology, 2009, vol. 16, no. 1.

103 This and the next claim are based on focus discussions and on my interviews with eight civil society members in Gulu, Uganda, in 2011 and 2012. 
ICC's potential to provide reparations and assistance, and felt that association with the Court was less risky.

In Kenya, survivors believed that their interactions with Court staff could expose them to retaliation by supporters of accused persons. Interviews with Court staff who worked in Kenya and with Kenyan civil society actors who assisted the ICC confirmed these fears. They also claimed that they were under regular surveillance by state-affiliated actors in Kenya, and believed that the ICC lacked sufficient capacity in Kenya to address all the security concerns faced by witnesses and participating victims. ${ }^{104}$

Finally, international criminal tribunals have very complex interactions with the political opportunity structures in the countries where crimes occurred, as well as at regional and international levels. For instance, the ICC's intervention in Uganda was encouraged by international attention to the civil war in Uganda, and to some extent helped reduce international criticism of the Ugandan government's role in that war. ${ }^{105}$ This international attention also contributed to the Ugandan government's policies toward transitional justice, which were significant on paper but limited in implementation, and tended to minimize government or military complicity in crimes. ${ }^{106}$ The ICC's intervention has had ambiguous effects on opportunities for survivors of violence to engage in local, reparative justice measures. Paradoxically, international and local support for these processes may have been increased because of criticisms by Ugandan civil society of interference by a foreign, retributive Court. ${ }^{107}$

The ICC's intervention in Kenya provides a particularly powerful demonstration of how a shifting context can shape the Court's empowerment or disempowerment of victims. Between 2008 and 2010, many Kenyan politicians supported the ICC's intervention in Kenya, including MP William Ruto. During this period Kenya adopted a new constitution and improved the independence of its judiciary. Human rights organizations and other civil society actors were enthusiastic of these developments, and some believed that victims of the post-election violence would soon enjoy multiple avenues to pursue justice - including the ICC, domestic criminal courts, and Kenya's Truth, Justice and Reconciliation Commission. ${ }^{108}$

However, when the Prosecutor put forward charges against six individuals in 2010, politicians including Ruto and Uhuru Kenyatta began to mobilize their supporters against the Court. Kenyatta and Ruto, who had long been political opponents, united to form a new party that some referred to as the "alliance of the accused." 109 After winning the 2013 national elections, the Kenyatta and Ruto government actively resisted the ICC, both within Kenya and in regional and international

${ }^{104}$ Interviews with three Court staff in Nairobi and The Hague (2012 and 2014), and interviews with members of four civil society actors in Eldoret, Kisumu and Nairobi (2012).

${ }^{105}$ Nouwen and Werner, 2010.

${ }^{106}$ Arnould, 2015; Freeland, 2015.

${ }^{107}$ Interviews with four civil society members, Gulu, Uganda, 2011 and 2012. See also Sarah MH Nouwen, Complementarity in the Line of Fire: The Catalysing Effect of the International Criminal Court in Uganda and Sudan, Cambridge University Press, Cambridge, 2013.

${ }^{108}$ Interviews with four staff of human rights NGOs, Nairobi, Kenya. May - August, 2012.

${ }^{109}$ Gabrielle Lynch, "Electing the 'Alliance of the Accused': The Success of the Jubilee Alliance in Kenya's Rift Valley," in Journal of Eastern African Studies, 2014, vol. 8, no. 1. 
politics. ${ }^{110}$ The ICC Prosecutor has argued that its investigations were systematically undermined, and witnesses and victim participants expressed fears of increasing threats to them. ${ }^{111}$ Several key witnesses for the Prosecution recanted their testimony or refused to testify, and all cases eventually collapsed before any trials reached completion. In addition, since 2013 the Kenyan government has increasingly cracked down on Kenyan human rights organizations, which had been supportive of the ICC and of accountability, truth and reparations for victims. ${ }^{12}$ This backlash has undermined the political opportunity structure for survivors and allies to pursue their justice aims. Amidst these developments, victims have seen little accountability or reparations for crimes against them.

\section{Conclusion}

This chapter argues that international criminal tribunals' impact on the agency of people labeled victims is complex and multi-dimensional. I propose that international criminal tribunals do not simply empower or disempower all 'victims,' but that they can provide resources or opportunities for certain people to pursue certain aims in certain contexts. More specifically, tribunals are selective about who receives victim status, they channel people's agency in particular ways, their impact is highly context-dependent rather than being consistent across different social and institutional circumstances.

Research with survivors of violence show that they seek, compete over, utilize, and are frustrated by victim status from the ICC. In Kenya and Uganda, the Court and its in-country officers were seen as possible sources of assistance to advance diverse justice aims, ranging from directly providing material assistance and prosecuting perpetrators to more indirect improvements of community recognition or political opportunity structures. However, people's lack of influence over selectivity and channeling, combined with the Court's struggle to achieve its own mandate in difficult contexts, led to frustration and - in some cases - the disempowerment of some survivors' pursuit of justice.

By paying attention to selectivity, channeling, and context dependence, we can better understand different forms of empowerment and disempowerment. For instance, to return to the categories of disempowerment in Section One, people with victim status are at risk of harm due to their direct interactions with tribunal staff but also due to the security context in their home country. Concerns about the powerlessness and instrumentalization of victims become clearer when we distinguish between their opportunities for channeled agency in international criminal justice processes, and their very limited opportunities to shift the type or timing of action that tribunals might take. This channeling, as well as extensive selectivity of tribunals, also help explain why many survivors may find that the time, effort and hope that they invest in tribunals may not lead to new opportunities to pursue justice. This displacement of agency to promote justice can also occur when tribunals

${ }^{110}$ Laurence R. Helfer and Anne E. Showalter, "Opposing International Justice: Kenya's Integrated Backlash Strategy against The," in International Criminal Law Review, 2017, vol. 17, no. 1

${ }^{111}$ Lynch, 2014.

112 Thomas Obel Hansen and Chandra Lekha Sriram, "Fighting for Justice (and Survival): Kenyan Civil Society Accountability Strategies and Their Enemies," in International Journal of Transitional Justice, 2015, vol. 9 , no. 3 . 
worsen survivors' opportunity structure to pursue justice via other institutions or political processes.

This chapter's analysis also provides another perspective on the power and weakness of international criminal tribunals, and in particular the ICC. On the one hand, the ICC and affiliated actors are privileged players in international and often domestic politics, able to mobilize the resources of the Court and often the support of states and civil society organizations. However, the effective power of the Court to pursue its stated aims for victims is often quite limited, and can put victims at risk. This is particularly clear when a government or other powerful local actors resist the Court. Paradoxically, then, the weakness of the ICC may increase risks that it will disempower victims. The arc of the ICC's activities in the Kenya situation provide a stark illustration of these challenges.

More research is needed to deepen this analysis. In particular, when it comes to the ICC, longterm, longitudinal studies of people granted victim status are needed to reveal how their interactions with the Court and their opportunities to pursue justice may shift over time. Such research can inform the practices and policies of international criminal justice institutions. Perhaps more importantly, it could help inform the strategies of survivors of injustice and their allies, so they can better decide when to pursue justice by engaging these institutions and when to direct their agency and hope elsewhere. 